A N N A LES

UNIVERSITATIS MARIAE CURIE-SKŁODOWSKA

LUBLIN - POLONIA

VOL. XIV, 1

SECTIO L

2016

Instytut Sztuk Pięknych UMCS

Marcin Maron

Miłość, śmierć i romantyczna „choroba wieku”. Film Błękitna nuta Andrzeja Żuławskiego jako romans historyczny

Love, Death, and "Romantic Malady of the Age". The Film La Note Bleue

[The Blue Note] by Andrzej Żuławski as a Historical Romance

Śpiewać-i nie ma komu!

Kochać - i nie ma kogo....

Bohdan Zaleski

Schowajmy się na po śmierci...

Fryderyk Chopin

Błękitna nutę - film Andrzeja Żuławskiego zrealizowany w 1990 roku widzieć można jako bardzo osobiste dzieło tego reżysera. Odnajdujemy w nim dwa zasadnicze tematy jego twórczości, ukryte w opowieści o geniuszu muzyki: historię miłości oraz powikłane doświadczenia polskiego artysty-emigranta ${ }^{1}$.

Żuławski jasno sprecyzował główne problemy filmowego dramatu. W pierwszej płaszczyźnie znaczeń miał to być film o Fryderyku Chopinie, artyście-emigrancie

\footnotetext{
${ }^{1}$ „Miałem wrażenie, że go dobrze rozumiem, że znam tę sytuację. Wiem, co to znaczy być wywiezionym z Polski. Nawet rozumiem francuskość Pana Fryderyka...”- mówił po latach reżyser. Żuławski. Przewodnik Krytyki Politycznej (wywiad rzeka), P. Kletowski, P. Marecki, Warszawa 2008, s. 388.
} 
i jego trudnym związku uczuciowym z George Sand. W tym sensie opowiada on „o parze, chyba centralnym temacie każdego mego filmu”" - mówił reżyser.

Twórca oparł swoje dzieło na autentycznych źródłach historycznych - biografiach, wspomnieniach, korespondencji. Stworzył jednakże wyimaginowany obraz jednego dnia z życia Chopina i bliskich mu osób, który spędzić mogli oni wspólnie w lecie roku 1846, w Nohant, wiejskiej posiadłości należącej do George Sand. Reżyser starał się unikać psychologizowania, podobnie jak Chopin unikał w swoich kompozycjach bezpośredniego imitowania natury. Ten brak pozorów realizmu zastąpił Żuławski dążeniem do uzyskania maksymalnej esencjonalności uczuć. Osiągnął ją zaś za pomocą ekspresji gry aktorskiej, kształtu obrazu i muzyki.

Metoda twórcza Żuławskiego pozwoliła wyrazić skrajne uczucia, ale także oddać wyjątkowy charakter ludzi, wśród których się one zrodziły. Bohaterami filmu są artyści. Efekt autentyzmu wzmacnia muzyka Chopina. Wybitny pianista Janusz Olejniczak, który wcielił się w postać kompozytora, grał ją bezpośrednio na planie zdjęciowym. W ten sposób dramat ludzkich namiętności podniesiony został do rangi sztuki.

Ta filmowa opowieść posiada jednakże bardzo konkretne umocowanie w faktach znanych biografom Chopina oraz w historycznym tle epoki romantyzmu. Problemy te stanowią pierwszą (niejedyną) warstwę znaczeń dzieła Andrzeja Żuławskiego. Spróbujmy się jej przyjrzeć...

\section{Węzel uczuć}

Do Nohant przybywają goście, których wita przed domem George Sand (Marie France Pisier). Z rozjaśnionego słońcem pleneru kamera przenosi nas do ciemnych wnętrz domu, skąd dobiegają delikatne dźwięki Barkaroli, granej przez Chopina w jednym z pokoi na piętrze.

W filmowym Nohant, obok Chopina, George Sand i jej dzieci - dwudziestoczteroletniego Maurycego i osiemnastoletniej Solange (Sophie Marceau) przebywają już inni letnicy. Są tutaj malarz Eugene Delacroix (Feodor Aatkine), jeden z najbliższych paryskich przyjaciół Chopina, zafascynowany jego osobą i muzyką, bliski także pani domu, Paulina Viardot (Noemi Nadelmann), śpiewaczka, której talent Chopin podziwiał i z którą występował na domowych i publicznych koncertach, zaprzyjaźniona z George Sand. Są również osoby mniej lubiane, które stanęły pomiędzy Chopinem a jego przyjaciółką - Augustyna

${ }^{2}$ A. Żuławski, w: Opętanie. Ekstremalne kino Andrzeja Żuławskiego, red. S. Naitz i Alpe Nadria Cinema, (brak nazwiska thumacza), s. 39. 
Brault (później - Bertholdi), przybrana córka George, która przebywała na stałe w Nohant od stycznia 1846 roku i z którą Maurycy romansował za cichym przyzwoleniem matki. Jest też Jan - troskliwy służący kompozytora, niezbyt jednak lubiany przez francuskich gospodarzy.

Jedni odjeżdżają z Nohant, tak jak zakochany w Paulinie Viardot pisarz rosyjski Iwan Turgieniew, inni właśnie tu przybywają. Obok Francuzów - Louisa Viardot (Serge Ridoux), męża Pauliny, dyrektora Teatru Włoskiego w Paryżu oraz Fernanda Preaulx (Gilles Detroit) - miejscowego szlachcica, zaręczonego z Solange, człowieka poczciwego, lecz niezbyt rozgarniętego, przyjeżdżają też Polacy: Wojciech Grzymała (Roman Wilhelmi), przedsiębiorca, starszy o siedemnaście lat przyjaciel Chopina i „akuszer” jego związku z George, będący w bliskich kontaktach ze stronnictwem Adama Czartoryskiego oraz egzaltowana hrabina, Laura Czosnowska (Grażyna Dyląg), której mąż zastrzelił się w roku 1831 z zazdrości, przyjaźniąca się z Chopinem i jego rodziną jeszcze przed wyjazdem kompozytora z Warszawy.

Później przybędą także inni: pisarz Aleksander Dumas-syn (Redjep Mitrovitsa) oraz rzeźbiarz Auguste Clesinger (Aurelien Recoing) - fatalna postać tego dramatu.

Scena śniadania spożywanego przez część tego towarzystwa w cieniu drzew w ogrodzie nieopodal domu jest kontynuacją filmowej charakterystyki bohaterów. Widzimy obraz swobodnego życia toczącego się w posiadłości artystów, wśród przyjaciół - jedzenie, picie, muzyka, śpiew i lekka z pozoru konwersacja. Jednakże wszystko to szybko okazuje się podszyte wzajemnymi animozjami i frustracją. Scena ta sygnalizuje trzy zasadnicze linie tematyczne filmu, splecione ze sobą i rozwijające się później w toku wydarzeń dnia. Najważniejszy jest oczywiście wątek miłosny George Sand i Chopina, który dotyczyć będzie nie tylko miłości, ale również rodzinnej i egzystencjalnej sytuacji, w jakiej oboje znaleźli się w tym czasie.

Mamy też problem polskich emigrantów, z Chopinem na czele. Sprawa polska daje o sobie znać także w szerszym, historycznym kontekście, w opowieści o wydarzeniach krwawej rabacji galicyjskiej, która miała miejsce na wiosnę roku 1846. Istotę tych wydarzeń bezskutecznie starają się wytłumaczyć Francuzom Czosnowska, która przybyła właśnie z Polski, i Grzymała. Wątek „rodzinny” (miłość i egzystencja) i wątek ,polski” (emigracja) prowadzą wprost ku trzeciemu tematowi filmu: problemowi sztuki. „Umieram a pełno we mnie muzyki. Nie pamiętam już polskich pejzaży" - mówi w pewnym momencie Chopin.

Główni bohaterowie - Chopin i Sand - znajdują się w niebezpiecznym momencie przesilenia. Czują pełnię swoich możliwości twórczych i życiowych, ale zarazem obojgu towarzyszy dojmujące poczucie przemijania i kresu. W istocie, 
lato 1846 roku spędzone w Nohant było ostatnim rozdziałem ich wspólnego życia, lecz bynajmniej nie ostatnim mocnym akordem ich związku.

Związek ten doczekał się licznych biograficznych interpretacji i dociekań. Oboje relacjonowali go w swojej korespondencji. Wracał on w opowieściach osób trzecich oraz w autobiograficznej książce pt. Dzieje mojego życia, którą opublikowała George Sand ${ }^{3}$. Wzbudzał skrajne emocje i przeciwstawne opinie. Jak zauważył Jarosław Iwaszkiewicz:

„Cała sprawa ma tyle aspektów, ile ma każdy stosunek dwojga wybitnych ludzi, i aspektów tych rodzi się tym więcej, im bardziej analizuje się to zagadnienie. Nie można być tutaj ani zwolennikiem George Sand, ani zwolennikiem Chopina. Oboje zaplątali się w sieci, które stawiała im ich własna natura, oboje należeli do tego typu ludzi, którzy raczej ze wszystkiego mogli zrezygnować aniżeli wyrzec się własnej natury" 4 .

Film Żuławskiego kondensuje wydarzenia i nastroje życia Chopina i Sand z lat 1845-1847. Jednak jego akcja nie bez przyczyny rozgrywa się właśnie latem 1846. Jak zauważył Mieczysław Tomaszewski, tego lata, mimo ożywionej atmosfery panującej w Nohant „czuło się grę pozorów i sztuczną wesołość”.

Lato 1846 nie było tak burzliwe, jak przedstawił to Żuławski w filmie, ale kryzys związku Sand i Chopina niewątpliwie mocno się pogłębił. Chopin przebywał w Nohant od końca maja. Na lipiec przypadły wizyty Laury Czosnowskiej i Grzymały, a dopiero po ich wyjeździe, w sierpniu, pojawił się Delacroix. Nie wszyscy byli tu jednak tak mile widziani jak on. Konflikt narastający wokół osoby Jana - wieloletniego służącego Chopina, za którym nie przepadała Sand, a z którego w obcesowy sposób naigrywał się Maurycy, rozwiązany został przez kompozytora jeszcze rok wcześniej. Mimo przywiązania Chopin oddalił go, nie chcąc pogarszać domowej atmosfery (w filmie następuje to dopiero w owym feralnym roku 1846). Drugą jednak osobą prowokującą wzajemne nieporozumienia była adoptowana przez Sand Augustyna.

„Augustyna i Maurice nawiązali romans. Solange nudziła się. Była zazdrosna o Augustynę, która zdawała się przyciągać większą uwagę niż ona, więc zaczęła flirtować z Chopinem, który stopniowo przelał na nią swe uczucia, zawiedziony postawą jej matki” ${ }^{6}$ - streszcza tę sytuację jeden z biografów kompozytora.

${ }^{3}$ G. Sand, Dzieje mojego życia, tłum. M. Dramińska-Joczowa, Warszawa 1968.

${ }^{4}$ J. Iwaszkiewicz, Chopin, Kraków 1984, s. 179.

${ }^{5}$ M. Tomaszewski, Chopin i George Sand. Miłość nie od pierwszego spojrzenia, Kraków 2010, s. 170 .

${ }^{6}$ A. Zamoyski, Chopin. Ksiązę romantyków, tłum. M. Ronikier, Warszawa 2010, s. 212. 
Jak zauważył Ferdynand Hoesick, „od wejścia Augustyny pod dach domu Pani Sand - zaczęły się wytwarzać jakieś przykre dysonanse w jej pożyciu z Chopinem" 7 .

Domownicy podzielili się w pewnym sensie na dwa „stronnictwa” $\mathrm{Z}$ jednej strony Maurycy i Augustyna, z drugiej - Chopin i Solange. Sand, co prawda, starała się zachować dystans, ale nie bardzo jej to wychodziło. Rozdrażnienie Chopina pogłębiał niespodziewany kryzys twórczy, jaki dotknął go właśnie tego lata, jak również niezbyt przychylne uwagi Sand i Maurycego na temat Laury Czosnowskiej, której pobyt w Nohant dał mu okazję do rozmów w języku polskim, przede wszystkim zaś do wspomnień o kraju i rodzinie. Chopin żalił się w pisanym w październiku liście do rodziny:

„Pisałem Wam o Lorce. Jakkolwiek grzeczni tu byli dla niej (...) kuzynce się nie podobała, a więc i synowi - stąd żarciki, z żarcików grubiaństwa, a ponieważ mi się to nie podobało, więc ani już mowy o niej nie ma"8.

Jakieś jednak na ten temat rozmowy być musiały, a zapewne także nie tylko na ten, skoro jeszcze w lipcu Sand pisała w swoim liście do Marie de Roziers:

„Pomogło mi to powiedzieć kilka słów prawdy i zagrozić, że kiedyś mogę mieć tego dość. Od tego czasu jest rozsądny, a wie Pani, jaki jest dobry, wspaniały i podziwu godzien, kiedy nie szaleje..."

Chopin najwyraźniej „nie szalał”, bo choć był coraz bardziej zniechęcony atmosferą panującą w Nohant, został tam aż do początku listopada. W październiku pisał do rodziny w sposób o wiele bardziej dyskretny niż czyniła to jego partnerka:

„Całe lato tutaj zeszło na rozmaitych spacerach i ekskursjach (...) Nie byłem de la partie, bo mnie te rzeczy więcej męczą, jak warto. Jakem zmęczony, takem niewesoły, a więc i wszystkim to na humor wpływa i zabawa mniejsza ze mną młodym" ${ }^{10}$.

\footnotetext{
${ }^{7}$ F. Hoesick, Chopin. Życie i twórczość, t. 3, Rozdźwięki, „Nella miseria” 1845-1849, Kraków 1966, s. 21.

${ }^{8}$ F. Chopin do rodziny [Nohant 11 października 1846], [w:] Korespondencja Fryderyka Chopina z George Sand i jej dziećmi, oprac. K. Kobylańska, Warszawa 2010, s. 558.

${ }^{9}$ G. Sand do Marie de Rozieres [Nohant, 24 lipca 1846], thum. J. Hartwig, (wszystkie listy G. Sand), [w:] ibid., s. 471.

${ }^{10}$ F. Chopin do rodziny [Nohant, 11 października 1846], ibid., s. 473 (przypis 3).
} 
Wątek dogasającej miłości i przyjaźni między dwojgiem głównych bohaterów stanowi nić przewodnią filmu. Reżyser powiązał go jednak z całością skomplikowanych relacji uczuciowych między bohaterami, tak że tylko momentami staje się on pierwszoplanowy. Obojgu głównym bohaterom towarzyszą sprzeczne uczucia i myśli. Pragnieniu miłości i zrozumienia przeciwstawia się narastająca świadomość końca. Sand stara się rządzić. Chopin chowa się w pokoju na górze i gra. Mijają się w wielkim domu pełnym gości.

W owym czasie - jak ujął to Kazimierz Wierzyński - „materia ich życia, to co było między nimi wspólne, przywiązanie, ufność, wzajemna potrzeba, zużywała się i rzedła"

Filmowa Aurora, w świetnym wykonaniu Marie-France Pisier, to kobieta piękna, dojrzała, w pełni świadoma swej siły, ale też słabości. Dla filmowej charakterystyki tej postaci ważna jest już pierwsza scena, kiedy to po przywitaniu gości Sand odprowadza wyjeżdżającego Turgieniewa do bramy ogrodu. Jawi się ona wtedy jako „socjalistka” o jasno sprecyzowanych poglądach na życie. Jest serdeczna i apodyktyczna zarazem, łagodna i impulsywna. To kobieta z ukrytą tajemnicą, do której nikt oprócz niej nie ma dostępu. Jej wspomnienie o wymyślonym przez siebie w dzieciństwie ,prywatnym bóstwie”, nazwanym Corambe, ukrywającym się w ogrodzie otaczającym pałac w Nohant, bogu ,ironicznym, lecz pozbawionym pogardy w stosunku do ludzi" - jak sama go charakteryzuje - staje się tu tyleż synonimem jej romantycznej wyobraźni, co bardziej jeszcze niezaspokojonej potrzeby miłości. Jest ważnym sygnałem prawdziwych przeżyć, jakie dręczyły małą Aurorę - odrzuconą przez matkę, wychowywaną przez apodyktyczną babkę, ogarniętą żarem swoistej uczuciowości, która najpierw skłaniała ją ku wstąpieniu do klasztoru, by później rzucić w ramiona kolejnych męż$\operatorname{czyzn}^{12}$. Owo nigdy w pełni niezaspokojone pragnienie miłości było esencją jej życia i głównym tematem twórczości.

„Miłość była dla niej nieustanną niespodzianką i cały swój wysiłek pisarski poświęciła, by wyjaśnić jej hipnotyczną siłę i określić jej miejsce w życiu społecznym ${ }^{13}$ " - pisał Kazimierz Wierzyński. W życiu Sand przeżycie miłości łączyło się zatem z literackimi i społecznymi wyobrażeniami na jej temat. Nie zawsze jedne pokrywały się z drugimi. Tak, z biegiem czasu, było także $\mathrm{w}$ jej związku z Chopinem.

W scenie śniadania pod drzewem filmowa Sand wspomina narodziny swojej miłości do Fryderyka. Przywołuje nawet słynny list napisany do Grzymały, który

\footnotetext{
${ }^{11}$ K. Wierzyński, Życie Chopina, Kraków 1978, s. 306.

${ }^{12}$ Zob. ibid., s. 226-227. „Chciałam go kochać tak jak przyjaciela, jak siostrę, a jednocześnie wielbić go jak boga". Sand, op. cit., s. 186.

${ }^{13}$ Wierzyński, op. cit., s. 233.
} 
rozpoczął jej starania o względy Chopina. Jeszcze padają słowa „kocham cię”. Jednakże szczerość i autentyczność uczuć (według Sand zamienionych już tylko w „matczyną” troskliwość), przesłonięta zostaje wzajemną animozją i gwarem towarzystwa. Pod maską kobiety zdecydowanej, niewolnej od złośliwości, Sand jawi się w gruncie rzeczy jako osoba zmęczona i zalękniona o przyszłość rodziny. Jej reakcje wydają się skrajne. Narastające poczucie samotności oraz nieodparta potrzeba emocji pcha ją do flirtu z Delacroix. Szuka uczucia u Pauliny Viardot. Coraz bardziej irytuje ją, a nawet przeraża, chorobliwy stan Chopina i jego wycofanie w muzykę. Jej gwałtowna reakcja przerywa ekstatyczne wykonanie Etiudy Rewolucyjnej odgrywanej przez kompozytora gościom zebranym w salonie. W końcu wprost prosi Grzymałę, aby wyjeżdżając z Nohant, zabrał on ze sobą Chopina.

W ujęciu Żuławskiego, związek Sand i Chopina od początku okazuje się jako źle dobrany. Świadczą o tym słowa wypowiedziane przez Aurorę: „Ludzi się nie zmieni. Nie stałeś się kobietą, ani ja mężczyzną".

Potężny ładunek sprzecznych uczuć niesie także filmowy Chopin. Żuławski stworzył wizerunek człowieka wyjątkowego, artysty, który ma świadomość nieuchronności przemijania i tragizmu losu. Chopin jawi się jako człowiek wycofany w świat wyobraźni, bez reszty oddany muzyce, zmagający się z własnym geniuszem i chorobą. Ten stan rzeczy nie przeszkadza mu jednak widzieć, że jego partnerka „cierpi w miłości”, a zarazem, że „opanował ją szał zmian”, czego dowodem jest przeprowadzany w Nohant remont domu. Jest świadomy kryzysu, w jakim znalazł się ich związek, ale pozostaje bierny. Przenika go silne poczucie ciężaru upływającego czasu. „Nie jesteśmy już romantyczni, młodzi, piękni, delikatni" - konstatuje wobec niosącego go na rękach służącego Jana.

Tylko muzyka może przynieść jakąś formę ocalenia. I to jednak ma swoją cenę: ,Jestem konformistą a żyłem z najmniej konformistyczną z kobiet” - przyznaje $\mathrm{w}$ rozmowie $\mathrm{z}$ Grzymałą i, jak gdyby na potwierdzenie tych słów, ulega presji domowników i odprawia polskiego służącego, ponieważ „nie można mieć dwóch matek". Mimo narastającego poczucia obcości, jakie towarzyszy mu w Nohant, przyznaje, że ,tutaj jest moje schronienie, mój azyl, mój kokon. Umrę, jeśli tego zabraknie" - zwierza się Grzymale w odpowiedzi na jego zarzuty pod adresem pani Sand.

Chopin w wykonaniu Olejniczaka to człowiek delikatny i subtelny, ale odznaczający się także chorobliwą drażliwością. Łączy w sobie skrajne zachowania, tak jak jego pierwowzór - powściągliwość i skłonność do ironicznej błazenady, słabość fizyczną i siłę ducha, która przejawia się, kiedy gra na fortepianie.

Żuławski starał się oddać racje obu stron dramatu. Stworzył postacie wielowymiarowe, żywe, niosące w sobie zarazem wiele dobrych i złych cech, właści- 
wych zwłaszcza namiętnym naturom oraz artystom. Jego zabiegi szły w kierunku „uczłowieczenia” Chopina, ściągnięcia go z narodowego koturnu, na jaki wsadziła go biografistyka i postromantyczne stereotypy.

O tym jednak, że jego sympatia sytuuje się bardziej po stronie Chopina niż Sand, świadczy między innymi scena odczytywania przez pisarkę fragmentów powieści pt. Lukrecja Floriani. Dla wielu biografów Chopina powieść ta i jej publiczne odczytanie, które rzeczywiście miało miejsce w roku 1846 (choć raczej nie w Nohant), może służyć jako dowód na narastające w Sand pragnienie zakończenia związku z kompozytorem. Powieść ta miała być swoistą, podświadomą „próbą wyzwolenia się George Sand ze stosunku z Chopinem” 14 .

Sand pisała ją w Paryżu późną wiosną roku 1846. Powieść opowiada o nieudanym związku miłosnym aktorki Lukrecji Floriani z nadwrażliwym księciem o imieniu Karol. Związek ten, początkowo idylliczny, z czasem zamienia się w wielkie rozczarowanie. Bohaterka poświęca kochankowi swoje życie rodzinne i emocjonalne, opiekuje się nim, ale ten powodowany niezrozumiałym niepokojem oraz chorobliwą zazdrością najpierw doprowadza ją na skraj obłędu, a w finale do śmierci. W opisach zachowań Karola, Sand zawarła wiele cech właściwych Chopinowi. Jednakże powieść ta, zdaniem wielu jej krytyków, podporządkowana została przede wszystkim opisowi cierpień bohaterki. Wyłania się z niej portret kobiety poniżonej, ofiary źle ulokowanych uczuć.

Jak pisał Adam Zamoyski, „centralnym tematem powieści jest stopniowa transformacja łagodnego charakteru księcia Karola, wywołana przez jego «chorobę», która z kolei zabija Lukrecję"15. Jednym z głównych zarzutów postawionych bohaterowi powieści było stwierdzenie, że jedynym prawdziwym uczuciem, do jakiego był on zdolny, była miłość synowska ${ }^{16}$.

Zamoyski jednoznacznie stwierdził, że Sand publikując powieść, ,upokorzyła Chopina na forum publicznym", choć on sam nie dostrzegł (lub starał się nie dostrzec) żadnych podtekstów ${ }^{17}$. Natomiast Jarosław Iwaszkiewicz był zdania, że Lukrecja Floriani stała się „ostatnim gwoździem do trumny ich stosunku i przyjaźni"18.

${ }^{14}$ Ibid., s. 303.

${ }^{15}$ Zamoyski, op. cit., s. 210.

${ }^{16}$ Zob. Wierzyński, op. cit., s. 301, por. Tomaszewski, op. cit., s. 161.

${ }^{17}$ Zob. Zamoyski, op. cit., s. 210-212.

${ }^{18}$ Iwaszkiewicz, op. cit., s. 195. Natomiast Kazimierz Wierzyński uważał, że w powieści „nie znać świadomej lub nieświadomej złośliwości”, chociaż w swoim komentarzu na jej temat, zauważył nie bez racji, iż z opisu postaci Karola tak bardzo kojarzącego się z Chopinem wynika przede wszystkim, że po ośmiu latach zażyłości pozostał on dla Sand „niezrozumiały i w gruncie rzeczy obcy”. Wierzyński, op. cit., s. 302. 
Książka Sand wzbudziła mieszane uczucia wśród najbliższych przyjaciół pary. Heine i Delacroix ocenili ją bardzo krytycznie.

Heine paradoksalnie stwierdzał: „Ta emancypantka obeszła się obelżywie z moi przyjacielem Chopinem w obrzydliwej powieści, bosko napisanej”"19. Natomiast Delacroix wyznawał: „Przechodziłem męczarnie podczas czytania - ofiara i egzekutor zadziwiali mnie na równi. Pani Sand wydawała się zupełnie spokojna, a Chopin nie ustawał w pełnych zachwytu uwagach na temat opowiadania" ${ }^{20}$. Podobnie wygląda reakcja Delacroix w filmie.

Całość tej historii można podsumować słowami Mieczysława Tomaszewskiego, który napisał, że Lukrecja... „przyniosła nowy dowód na słuszność zarzucanego Sand procederu, polegającego na kończeniu kolejnych romansów przez umieszczanie swych kochanków w kolejnych powieściach"21. W filmie ten „literacki chwyt” Sand stosowany w stosunku do rzeczywistości przejawia się w stwierdzeniu: „Wystarczy poświęcić głównego bohatera, zamiast zabijać wszystkich pozostałych".

Ważne jest jednak, że Żuławski nie zakończył filmowej opowieści o związku Sand i Chopina na tym „plotkarskim” epizodzie. Tworząc przedstawienie miłosnej relacji, potrafił wznieść się wyżej. Bo też o nią właśnie chodziło, a nie o psychologiczną wiwisekcję. Żuławski pokazał ludzi z bagażem dobrych i złych doświadczeń. Zachował zarazem tajemnicę ich przeżyć, motywacji i uczuć, nieraz sprzecznych i kolidujących ze sobą, niemożliwych w gruncie rzeczy do zracjonalizowania.

W finałowej scenie filmu mamy do czynienia z wyciszeniem emocji i z nastrojem zadumy. W czerwonym pokoju Chopin gra na fortepianie Nokturn, a Aurora zamyślona próbuje dosłyszeć w jego grze „błękitną nutę”. Pierwszoplanowa staje się muzyka i jej uczuciowa niejednoznaczność. Może Żuławski podzielał zdanie o swoich bohaterach wypowiedziane w filmie przez dwa tajemnicze bóstwa - Corambe i Demogorgona, iż „w głębi serca są oni godni podziwu”?...

Nie umniejsza to jednak faktu, że stosunki panujące w Nohant ukazane zostały jako wielce skomplikowane. Faktycznie, zwłaszcza relacje rodzinne pozostawiały wiele do życzenia. Były one efektem rywalizacji o uczucia, różnic charakterów, ale też wynikiem sposobu wychowania dzieci przez Sand ${ }^{22}$. Oczkiem w głowie pani

${ }^{19}$ H. Heine, cyt. za: Tomaszewski, op. cit., s. 160.

${ }^{20}$ E. Delacroix, cyt. za: Zamoyski, op. cit., s. 212.

${ }^{21}$ Tomaszewski, op. cit., s. 158.

${ }^{22}$ „Wychowywali się bezładnie” - oceniał Kazimierz Wierzyński - „Maurycy porzucił szkołę w 15 roku życia i chociaż miał wielu guwernerów, ani jego wykształcenie, ani maniery nie wznosiły go poza pospolitość. Od 1841 roku zaczął uważać się za artystę, studiował malarstwo z zapałem i pozyskał na to błogosławieństwo matki, jedynej przychylnej dla niego muzy. Solange 
domu był Maurycy. Im bardziej dorastał, tym wyobraźnia Sand coraz bardziej idealizowała jego osobę ${ }^{23}$. Solange oceniana była zupełnie inaczej. Matkę irytował jej temperament i buntownicze nastroje, które przeplatały się z bezmyślnością i apatią. Córka zaś bezskutecznie oczekiwała od matki przychylności.

„Solange pragnęła miłości matki, lecz matka pragnęła pieszczot syna i w marzeniach kochała go jak kogoś innego, dorosłego i nie do poznania ${ }^{24}$ ” - domniemywał Kazimierz Wierzyński.

W filmie Żuławskiego dwudziestokilkuletni już Maurycy zachowuje się jak przerośnięte dziecko. Jest zazdrosny i zarozumiały. Jego stosunek do Chopina to mieszanina podziwu i ostentacyjnej niechęci. Kompozytora razi jego impertynencja, bo pamięta go jeszcze jako przyjaźnie nastawionego, małego chłopca. Zadaje mu więc wprost pytanie: „Dlaczego stałeś się taki hardy?”

Maurycy pozostaje na uboczu towarzystwa przebywającego w Nohant. Brak pierwszoplanowej roli rekompensuje sobie zabawą kukiełkami, zaklinając rzeczywistość na swój sposób. Trawi go kompleks artysty. Choć pobiera lekcje malarstwa u Delacroix, to ,jest zręczny w malowaniu, ale bez boskiego natchnienia" - ocenia filmowa pani Sand.

Tymczasem Solange, w swym dziewczęcym idealizmie, pragnie wzniosłych uczuć. Pragnienia te podsyca piękno muzyki Chopina rozbrzmiewającej w Nohant. To Solange zdaje się przeżywać i czuć tę muzykę najsilniej. Z czułością pochyla się nad jej twórcą. Jej coraz bardziej ostentacyjna adoracja Chopina wzbudza zdumienie, a potem niepokój i zazdrość matki.

Jeśli promień miłości ożywia filmowe Nohant, to dzieje się tak właśnie za sprawą ,słońca” Solange. Żuławski wzmocnił relację miłosną Solange i Chopina. W filmie padają wyznania, które w rzeczywistości raczej nie padły. Początkowe zaloty zamieniają się na moment w prawdziwą czułość. Miłość zdaje się kruszyć najtwardsze przeszkody w scenie, w której Solange recytuje dla Chopina łamaną polszczyzną fragmenty Pana Tadeusza. Wzniosłość i delikatność uczuć biorą na chwilę górę nad czającym się niebezpieczeństwem katastrofy.

„Ojcowski” dystans i powściągliwość Chopina zostają w końcu przełamane. Fryderyk daje się ponieść złudzeniu szczęścia, ale szybko rozwiewa się ono wraz z przybyciem Clesingera. Odtąd oczy i serce Solange zwracają się w inną stronę.

rosła w mniej szczęśliwych warunkach. Wędrowała spod opieki matki pod opiekę ojca, od ojca do babki, od babki znów do matki (...) Rywalizowali więc o nią zazdrośnie. Szanse ich jednak nie były równe”. Wierzyński, op. cit., s. 293.

${ }^{23}$ Wyraźny ślad tej idealizacji dostrzec można w jej korespondencji z przyjaciółmi. Maurycy jawi się tam jako „istota najlepsza, najłagodniejsza, najbardziej zrównoważona, najpracowitsza, najprostsza i najuczciwsza, jaką można spotkać”. Cyt. za: Tomaszewski, op. cit., s. 161.

${ }^{24}$ Wierzyński, op. cit., s. 294. 
Żuławski podsycając miłosną relację Solange i Chopina, wydobywając ją niejako na światło dzienne, odszedł od historycznych realiów. Jeśli zauroczenie Chopina było rzeczywiste, to okazywał on je w sposób o wiele bardziej powściągliwy. Prawdą jest natomiast, że Solange zaczęła w pewnym momencie zabiegać o jego względy ${ }^{25}$. Oboje potrzebowali uczuć - trawiło ich poczucie osamotnienia - tak różne u obojga.

„Solange kłócąc się z Chopinem pokazując mu swe pazury i ząbki, nadawała atakom charakter pótflirtu. Gra stawała się niebezpieczna" - oceniał Jarosław Iwaszkiewicz ${ }^{26}$.

„Solange nie znała miłości, a sympatia do Chopina mogła być pierwszym jej substytutem. Fryderyk prawdopodobnie poddawał się także marzycielskiej słabości...”27 - snuł z kolei domysły Wierzyński.

O ile Żuławski przerysował w filmie wątek miłosny Solange i Chopina, nadając mu pierwszoplanowy status, o tyle potwierdzonym historycznie faktem jest to, że o rozstaniu Sand i kompozytora zadecydowała sprawa związku Solange i Clesingera. I nie chodziło tu bynajmniej o zazdrość „odtrąconego” Chopina.

Żuławski wiedział oczywiście, że sprawa małżeństwa Clesingera z Solange, która poróżniła ostatecznie Sand i Chopina, i która także rzuciła nieusuwalny cień na stosunki matki i córki, rozegrała się już po owym lecie 1846, ponad pół roku później. Dlatego wprowadził do filmu postać rzeźbiarza dopiero w końcowych sekwencjach filmu. Jego popołudniowe przybycie do Nohant zamienia panujące tam stosunki w farsę. Zaostrza także relację pomiędzy Sand a Chopinem.

Po wyjeździe Chopina z Nohant w listopadzie 1846 roku pani Sand przez kolejne miesiące pochłonięta była snuciem planów matrymonialnych dla swoich dzieci. Były dwa pomysły: ożenić Maurycego z Augustyną i wydać Solange za Fernanda de Preault. Na przełomie lat 1846/47 Sand i Chopin prowadzili ze sobą zwykłą korespondencję dotyczącą spraw codziennych. W lutym 1847 roku, po przyjeździe pisarki do Paryża, spędzali wspólnie czas wśród znajomych. Jeszcze pierwszego kwietnia tego roku odbyli z Delacroix spacer do Ogrodu i Pałacu Luksemburskiego, gdzie pokazywał on im swoje malowidła. „Potem kolacja u nich”. - Pisał malarz w swoim „Dzienniku” - „Wieczorem Pani Sand szła do Clesingera; zaproponowała mi bym jej towarzyszył, ale byłem bardzo zmęczony i wróciłem do domu" ${ }^{28}$.

${ }^{25}$ Zamoyski, op. cit., s. 206.

${ }^{26}$ Iwaszkiewicz, op. cit., s. 194.

${ }^{27}$ Wierzyński, op. cit., s. 298.

${ }^{28}$ E. Delacroix, Dzienniki. Część pierwsza (1822-1853), thum. J. Guze i J. Hartwig, wstęp J. Starzyński, Ossolineum 1968, s. 131. 
Sand poznała osobiście Clesingera podczas swojego pobytu w Paryżu w lutym $^{29}$. Znała go już jednak wcześniej z korespondencji. Przedstawiał się w niej jako wielki wielbiciel jej talentu oraz wyznawanych przez nią idei socjalistycznych ${ }^{30}$. W Paryżu rzeźbiarz spodobał się również córce. Toteż obie skwapliwie zgodziły się, aby w swojej paryskiej pracowni wyrzeźbił ich popiersia. Solange zakochała się w nim błyskawicznie, a jej matka szybko zmieniła plany matrymonialne i zaprosiła go do Nohant. Chopin był zdecydowanie przeciw temu nagłemu zwrotowi sytuacji. Nie ukrywał krytycznego zdania o Clesigerze. Pozostał w Paryżu, planując wyjazd na wieś dopiero na lipiec.

W relacjach biografów, Clesinger jawi się jako „nieokrzesany prostak”, pełen jednak „ognia i temperamentu” ${ }^{31}$. Służył w kawalerii i chciał zrobić karierę jako artysta:

„Trzydziestoletni Clesinger był niezbyt ciekawym człowiekiem, pijakiem i hazardzistą, ale Sand oczarowana jego żywiołową energią, widziała w nim jakby tworzącego w marmurze Delacroix" ${ }^{32}$.

Podobnie jest w filmie. Clesinger, od razu po przyjeździe do Nohant stara się omamić kobiety swą siłą, urodą i komplementami. Rozzuchwalony przychylną reakcją Sand, porywa córkę do pracowni rzeźbiarskiej, aby pokazać jej swój „kunszt”. Jest egzaltowanym kabotynem, który mimo swego rzekomego artyzmu, za całą definicję życia ma powiedzenie: „Małpy mają rację - reszta to kultura”. Podczas kolacji, która zamienia dramat w Nohant w farsę, dochodzi do zaręczyn. Tylko Delacroix, który miał z nim już do czynienia, głośno ostrzega zebranych...

W rzeczywistości ,atak” Clesingera na panie Dudevant był niemal równie błyskawiczny - trwał raptem dwa miesiące. Od kwietnia 1847 sprawy potoczyły się szybko, ale przybrały zaskakujący dla wszystkich obrót. Sand zataiła przed Chopinem plany małżeństwa Solange z Clesingerem, a potem datę ich ślubu. Nie życzyła sobie, by ten wtrącał się w jej rodzinne decyzje. Zdradziła przy tym nie tylko krótkowzroczność, ale także zadziwiającą niewiarę w inteligencję swojego przyjaciela. Była przekonana, że kieruje się on uprzedzeniami. Ona sama nie chciała „robić z Chopina głowy rodziny i rady familijnej; dzieci nie przystałyby na to i straciłaby na tym moja godność" ${ }^{33}$ - zwierzała się w jednym z listów.

\footnotetext{
${ }^{29}$ Zamoyski, op. cit., s. 217.

${ }^{30}$ Hoesick, op. cit., s. 71.

${ }^{31}$ Ibidem.

${ }^{32}$ Zamoyski, op. cit., s. 217.

${ }^{33}$ G. Sand do Marie de Rozieres [Nohant, 8 maja 1847], [w:] Korespondencja..., tłum. J. Hartwig (wszystkie listy Sand w tym tomie), s. 486.
} 
Bardzo się myliła. Już w czerwcu wyszły na jaw zatajone długi rzeźbiarza. Stosunek młodych do matki zmienił się. Clesinger bezceremonialnie zażądał pomocy finansowej. W lipcu doszło w Nohant do karczemnej awantury, z rękoczynami włącznie, która doprowadziła do gwałtownego rozstania matki z córką. Solange wygnana z domu wraz z mężem, nie mogąc dotrzeć do Paryża, zwróciła się listownie do Chopina o możliwość skorzystania z jego powozu, który garażował w Nohant, a którego odmówiła jej matka. Chopin, zaskoczony niespodziewanym listem, wyraził zgodę.

Gest ten, przyjacielski jedynie, uczyniony bez złych intencji, wzbudził furię pisarki. Zerwała stosunki z córką i obraziła się na Chopina. Zakazała mu listownie pomagać Solange i Clesingerowi. Jednak kompozytor, postawiony w bardzo niewygodnej sytuacji, nie odmówił im pomocy. Mimo swych zastrzeżeń do Clesingera pozostał z Solange w bliskich, ale jedynie przyjacielskich kontaktach. Widywali się w Paryżu. Solange była w ciąży, więc Chopin pożyczył im pieniądze. Pisali do siebie.

Sand przekonana była jednak, że buntuje on córkę przeciwko niej i manipuluje opinią paryskiego towarzystwa. Obok autentycznych emocji, czynnik ambicjonalny nie był tu bez znaczenia. Z licznych listów Sand do znajomych jasno wynika, że starała się ona usilnie przekonać ich do swoich „racji”. W jej odczuciach wyraźnie mieszały się: rozgoryczenie, urażona duma i zazdrość o Solan$\mathrm{ge}^{34}$. W listach tych oskarżała wprost Chopina o „stronniczość i nielojalność” ${ }^{35}$, o „gorzki charakter" i „humory” ${ }^{\prime 36}$.

Chopin był o wiele bardziej powściągliwy, ale i on nie omieszkał skomentować listownie absurdalnego rozwoju sytuacji. Sprawa ciągnęła się aż do roku 1848. „Niech ją Pan Bóg kocha, jeżeli nie umie rozeznać prawdziwego przywiązania od pochlebstw” - podsumowywał rozgoryczony w liście do siostry. „Za kaprysami takiej duszy nikt nie będzie mógł nigdy iść w tory. Osiem lat jakiegoś porządku to było za wiele. Pan Bóg dał, że to były lata, w których dzieci rosły, i żeby nie ja, nie wiem jak dawno by były już dzieci z ojcem, a nie z nią (...) Ale może też to są kondycje jej życia, jej talentu pisarskiego, jej szczęścia?" ${ }^{37}$ - zapytywał sam siebie.

Po awanturze z Clesingerem widzieli się jeszcze tylko raz, przypadkowo. Tak zakończył się ich związek. Sand pisała i wydawała teraz swoje wspomnienia; Chopin zaś czuł zbliżającą się śmierć...

\footnotetext{
${ }^{34}$ G. Sand do Emanuela Arago [Nohant, 18-26 lipca 1847], [w:] ibid., s. 497-499.

${ }^{35}$ G. Sand do Pauliny Viardot [Nohant, 9 listopada 1847], [w:] ibid., s. 507.

${ }^{36}$ G. Sand do Charlotty Marliani [Nohant, 2 listopada 1847], [w:] ibid., s. 503.

${ }^{37}$ F. Chopin do Ludwiki Jędrzejewiczowej [Paryż, 10 luty 1848], [w:] ibid., s. 565.
} 


\section{Dramat życia i emigracji}

Życie Chopina przebiegało w cieniu śmierci. Zasadniczy wpływ na taki stan rzeczy miała oczywiście choroba, źle diagnozowana i źle leczona gruźlica. Wrosła ona w osobowość kompozytora i stała się jej częścią. Chopin przeczuwał powagę sytuacji; starał się zagłuszyć dolegliwości siłą woli, pracą oraz intensywnym życiem towarzyskim. W ten sposób udało mu się przetrwać kilka poważnych kryzysów zdrowotnych, poczynając od tego, który nawiedził go podczas pobytu na Majorce, i który tak mocno wpłynął na charakter jego związku z Sand. Choroba stała się częścią jego wizerunku w oczach innych.

Jednakże nawet George Sand nie w pełni zdawała sobie sprawę z prawdziwych przyczyn złego stanu zdrowia przyjaciela. W roku 1846 określiła ten stan jako „wieczne i nieokreślone bliżej złe samopoczucie” ${ }^{38}$. Jeszcze w lutym roku 1847 ,instynkt” podpowiadał jej, ,że Chopin doczeka starości” ${ }^{39}$. Jak bardzo myliła się, pokazać miały dwa następne lata, kiedy ich drogi rozeszły się.

Ale i wcześniej choroba mocno dawała o sobie znać. Suchotniczy kaszel, krwotoki i chroniczne osłabienie utrudniały życie i pracę kompozytora. Obrazy tego zmagania ze śmiertelną chorobą stanowią istotny wątek filmu Żuławskiego. Motyw choroby Chopina wyeksponowany został przez reżysera mocno, dosadnie nawet, w obrazach krwotoków, które zalewają klawiaturę fortepianu podczas gry oraz w sposób metaforyczny - w barwie scenografii (czerwień pokoju) i oświetlenia (zielone refleksy na twarzy Chopina).

Piętno śmierci, którym przesycone jest życie w Nohant, daje o sobie znać także poprzez muzykę, zwłaszcza w scenie, w której Chopin gra skomponowany przez siebie Marsz Żałobny. Jego choroba oraz muzyka, tak bardzo tą chorobą naznaczona, przerażają Panią Sand. Nie mieszczą się w granicach jej pojmowania życia i sztuki. „On nie przestanie umierać” - mówi do Grzymały i prosi go, aby zabrał Chopina z Nohant.

„Wszystko mnie zabija” - przyznaje Chopin, lecz to właśnie stwierdzenie staje się dla niego impulsem do tworzenia. Jego życie napiętnowane jest śmiercią, ale prawdziwa sztuka i jej piękno rodzą się właśnie z bólu i cierpienia. Ta romantyczna koncepcja życia i twórczości ujawnia się w filmie Żuławskiego ze szczególna siłą. Jest obecna nie tylko w postawie Chopina. Daje o sobie znać także wraz z przybyciem do Nohant Aleksandra Dumasa-syna, który snuje opowieść o Damie kameliowej. W opowieści tej, tak jak w filmowym Nohant, miłość nierozerwalnie łączy się ze śmiercią, a piękno związane jest z chorobą i gniciem.

\footnotetext{
${ }^{38}$ G. Sand do Charlotty Marliani [Nohant, 3 października 1846], [w:] ibid., s. 476.

${ }^{39}$ G. Sand do Charlotty Marliani [Paryż, 11 lutego 1847], [w:] ibid., s. 483.
} 
Opowieść ta przesycona jest nieuleczalnym smutkiem i obsesją śmierci. Były to typowe objawy romantycznej „choroby wieku”, która nie ominęła także bohaterów Żuławskiego.

"Cała choroba obecnego stulecia" - pisał Alfred de Musset, twórca tego pojęcia i jeden z kochanków George Sand - „wywodzi się z dwóch przyczyn: naród, który przeżył rok 1793 i 1814, ma w sercu duże rany. Wszystko, co było, już nie istnieje; wszystko, co będzie, jeszcze nie istnieje. Nie szukajcie gdzie indziej tajemnicy naszych cierpieńt ${ }^{40}$ ".

Chodzi tu zarówno o doświadczenia historyczne, jak i o nowy rodzaj romantycznej psychologii wyczulonej na zmienność i nietrwałość świata. Romantyczna choroba wieku ujawniała się jako stan osobliwego zawieszenia pomiędzy przeszłością a przyszłością, pomiędzy realiami historycznymi a niezrealizowanymi ambicjami i marzeniami ludzi. Jej szczególną właściwością była tendencja do bezlitosnej analizy własnych stanów uczuciowych. Co ważne, analiza ta potęgować miała cierpienie doznawane przez „chorego”, stając się tym samym wyrazem swoistej delektacji własnym nieszczęściem.

Henri Peyre, analizując zjawisko „choroby wieku” w kontekście romantyzmu francuskiego, określił jej najważniejsze przejawy i proces, jakiemu najczęściej podlegała. Przebiegało to mniej więcej tak: poczucie historycznego zerwania ciągłości, wyobcowanie społeczne oraz zanik uczuć religijnych wyzwalały stan samotności. Ta sprzyjała wyostrzonej analizie uczuć. Potrzeba przywrócenia pełni doświadczenia, na przekór myślom zatruwającym uczucia, prowadziła do rozdwojenia. Wyimaginowane cierpienie stawało się źródłem swoistej przyjemności, wyzwalając zarazem obsesję śmierci ${ }^{41}$. Był to stan dobrze znany wielu romantykom, także tym z kręgu Chopina, jak choćby Eugeniuszowi Delacroix czy Astolphowi de Custin. Natomiast jak ognia strzegła się go George Sand. Niewykluczone, że znając już z własnego doświadczenia podobne romantyczne „przypadki” (de Musset!), widziała ona objawy tej „,choroby” w zachowaniu i nastrojach Chopina.

„Nieszczęsny wielki artysta był nieznośny w swojej chorobie”42 - pisała o Chopinie we wspomnieniach - ,Jego nadmierne wzruszenia przenosiły go niepostrzeżenie w jemu tylko znane rejony ${ }^{43}$ ".

${ }^{40}$ A. de Musset, cyt. za: H. Peyre, Co to jest romantyzm?, tłum. M. Żurowski, Warszawa 1987, s. $130-131$.

${ }^{41}$ Ibidem.

${ }^{42}$ Sand, Dzieje..., s. 330.

${ }^{43}$ Ibid., s. 332. 
Chopin, ten „powściągliwy” lub „bezwiedny”" ${ }^{44}$ romantyk, daleki był jednak od typowo romantycznej egzaltacji. Świadczą o tym relacje ludzi. Jednakże stan nazwany „chorobą wieku” nie był mu z pewnością obcy. I nie decydowały o tym jedynie fizyczne dolegliwości i dręcząca go obsesja muzycznego ideału. W nie mniejszym stopniu decydowały o tym jego osobiste doświadczenia, na które cień rzuciła historia. Stały się one przyczyną życia w swoistym rozdwojeniu.

Większość biografów Chopina za jeden z najważniejszych momentów przełomowych w jego życiu uznaje zdarzenia, które nastąpiły we wrześniu 1831 roku w Stuttgarcie, gdzie zatrzymał się on na kilka dni w drodze z Wiednia do Paryża. Młody kompozytor przeżywał wówczas bolesną rozterkę związaną z opuszczeniem kraju i decyzją pozostania za granicą. Zapisy w dzienniku, jaki wtedy prowadził, świadczą, że doznał głębokiej depresji ${ }^{45}$. Dramatyzm sytuacji potęgowały doniesienia o upadku powstania listopadowego i dokonywanej przez Rosjan pacyfikacji Warszawy. Pewnego wrześniowego wieczoru, po raz pierwszy chyba tak gwałtownie, Chopin przeniknięty został myślą o śmierci. Nie był to zwyczajny lęk, lecz bardziej jeszcze nieokreślone poczucie osobliwego zawieszenia pomiędzy życiem a śmiercią. Swój stan porównał do trupa, który wciąż pozostaje przy życiu:

„Czemuż żyjemy takim nędznym życiem, które nas pożera i na to nam służy, aby trupów robiło! (...) Widać więc, że śmierć najlepszy uczynek człowieka - a cóż będzie najgorszym? - narodzenie! (...) Więc niewiele mi brak do matematycznie ścisłego pobratania się ze śmiercią (...) Jakże mi dobrze... Tęskno! Tęskno i dobrze! Jakież to uczucie? Dobrze i tęskno, kiedy tęskno, to niedobrze, a jednak miło! - jest to stan dziwny. Ale i trup tak. Dobrze mu i niedobrze mu razem w jednej chwili. Przenosi się w szczęśliwsze życie i dobrze mu, żałuje przeszłego opuszczać i tęskno mu. To trupowi musi być tak, jak mnie było w chwili, gdym skończył płakaćt'"

Doświadczenie to zostawiło w Chopinie trwały ślad na całe życie. Naznaczyło go piętnem „romantycznej choroby wieku”, w sposób jemu tylko właściwy. Wyzwoliło specyficzną postawę wobec umierania. Wszystko to znalazło także wyraz w muzyce. „Razem z tęsknotą za Polską, zawodami miłosnymi, wreszcie chorobą, która go trapiła, wytworzyło w nim nastrój, który stale dominuje w jego utworach ${ }^{47 ”}$.

Maria Janion, Maria Żmigrodzka i Ryszard Przybylski dostrzegli w tych „śmiertelnych przeżyciach" Chopina typowo polski, romantyczny rytuał symbolicznej

\footnotetext{
${ }^{44}$ Zob. Iwaszkiewicz, op. cit., s. 152.

${ }^{45}$ Zamoyski, op. cit., s. 71.

${ }^{46}$ F. Chopin, cyt. za: A. Czartkowski, Z. Jeżewska, Fryderyk Chopin, Warszawa 1975, s. 161-162.

${ }^{47}$ Ibid., s. 164.
} 
śmierci ,ja" ${ }^{\text {"48. }}$ W wymiarze fantazmatycznym życie Chopina może zatem jawić się jako życie „upiora” ${ }^{49}$. „Symbolika «żywego trupa» to ryzykowna estetycznie próba opisu rozpaczy egzystencjalnej" ${ }^{50}$ - pisały Janion i Żmigrodzka. Ów stan egzystencji zawieszonej, życie „dla śmierci”, obsesja wyobcowania są przykładem polskiego wariantu romantycznej „,choroby wieku”. Podobnie jak losy Mickiewiczowskiego Gustawa, jak rozterki Zygmunta Krasińskiego spisane przez niego w listach, jak ,romans życia” z Godziny myśli Juliusza Słowackiego ${ }^{51}$.

Czy zatem także w ujęciu Żuławskiego Chopin-Olejniczak ma w sobie coś z upiora? „Żywy trup” to przecież wampir. Czy Chopin Żuławskiego ma coś z wampira? Jest tu coś na rzeczy - filmowy Chopin błądzi po Nohant niczym somnambulik. Jeśli jednak posiada skłonności wampiryczne, to są one nacechowane autodestrukcyjnie. Może to właśnie ma na myśli służący Jan, kiedy mówi, że Chopin „,zje swoje serce, wypije łzy”...

Tak, czy inaczej, filmowemu Chopinowi towarzyszy poczucie upiornego rozdwojenia. Dotyczy ono egzystencji, której właściwościami są: choroba, smutek, żal. Związane jest z doświadczeniem emigracyjnego osamotnienia. Dotyka ono zresztą nie tylko Chopina, ale także innych polskich bohaterów filmu.

Poczucie rozłączenia z bliskimi oraz intensywność wspomnień przenosiły Chopina z rzeczywistego „tutaj” we Francji, w przestrzeń wyobraźni. Stały się przyczyną swoistego wyobcowania. „Jestem jedną nogą u Was” - pisał do rodziny w roku 1845 z Nohant - „drugą w pokoju obok - gdzie Pani Domu pracuje - a wcale nie u siebie w ten moment - tylko, jak zwykle, w jakiejś dziwnej przestrzeni. Są to zapewne owe «espaces imaginaires»" ${ }^{52}$.

Znamienne jest, że słowa te padły na rok przed zdarzeniami pokazywanymi w filmie i dwa przed rozstaniem. Poszukiwanie domu rodzinnego w związku z panią Sand nie powiodło się. Ten fakt docierał do Chopina z coraz większą siłą.

„George Sand nie zamierzała włączyć go do swojej wspólnoty. Pobyt Chopina w Nohant był więc tylko miłą, a może zresztą niemiłą zabawą w dom, która

${ }^{48}$ Zob. R. Przybylski, Cień jaskótki. Esej o myślach Chopina, Kraków 1995, s. 45 oraz M. Janion, M. Żmigrodzka, Romantyzm i egzystencja, Fragmenty niedokończonego dzieła, rozdz. Fryderyk Chopin wśród bohaterów egzystencji, Gdańsk 2004, s. 105.

${ }^{49}$ „W fantazmacie ,żywego trupa” zawarł Chopin doświadczenie zatraty własnej tożsamości przy zachowaniu świadomości istnienia swego ,ja”. Przeżył więc wydrążenie własnej osoby z jej istoty. Kiedy umiera serce, człowiek staje się „żywym trupem”. - tłumaczył Przybylski. Zob. idem, op. cit., s. 58.

${ }^{50}$ Janion, Żmigrodzka, op. cit., s. 110.

${ }^{51}$ Ibidem.

${ }^{52}$ F. Chopin, cyt. za: R. Przybylski, op. cit., s. 179. 
świadczyła jedynie o potędze strasznego kompleksu wszystkich emigrantów ${ }^{53}$ " - pisał Przybylski.

Maria Janion dostrzegła w emigracyjnym poczuciu „osierocenia”, którego doświadczał Chopin, stereotypowe cechy losu polskiego emigranta ${ }^{54}$. Podobnie widział to Ryszard Przybylski:

„Kiedy emigranci polscy znaleźli się poza krajem, tutaj we Francji mogli więc posiadać jedynie mieszkanie. Dom został tam, w ojczyźnie. Ich świadomość została raz na zawsze rozdwojona. Chopin jest wyjątkowo przejmującym przykładem takiego rozdarcia" ${ }^{\text {" }}$.

Trzeba przyznać, że rok 1846, w którym rozgrywa się akcja filmu Żuławskiego, był pod tym względem szczególnie dramatyczny. Rozbudzone nadzieje na niepodległość, jakie pojawiły się na chwilę wraz z wybuchem powstania krakowskiego, utopione zostały w rzezi i chaosie rabacji galicyjskiej ${ }^{56}$. W środowiskach emigracyjnych szok mieszał się ze świadomością popełnionych błędów i reakcją konserwatywną. Charakterystyczne dla tych środowisk przekonanie o swoistej odrębności polskiej kultury oraz historii konfrontowało się z rosnącym we Francji nurtem postępowego romantyzmu francuskiego o zabarwieniu socjalistycznym. Należała do niego także George Sand. Nadzieje związane z tym nurtem wybuchły we Francji w roku 1848. Jednakże i one zostały wkrótce brutalnie rozwiane. „Dla pokolenia polskich romantyków był to straszliwy szok ${ }^{57 "}$ - podsumowywał Andrzej Walicki.

Ten stan emigracyjnego „zawieszenia” pokazał w filmie Żuławski. Jeśli przyjrzeć się towarzystwu zebranemu w filmowym Nohant pod kątem politycznym, to można stwierdzić, że stanowi ono swoistą mieszankę wybuchową. Są tu przedstawiciele francuskiego ziemiaństwa, konserwatysta, Rosjanin Turgieniew, i postępowcy pod egidą Sand. Na ich tle widzimy też Polaków - Chopina, Grzymałę i Czosnowską. Każdy z nich znalazł się we Francji z innych powodów.

${ }^{53}$ R. Przybylski, op. cit., s. 125.

${ }^{54}$ Wskazywała zarazem, że w życiu kompozytora nigdy nie doszło „do uzgodnienia ról artysty, obywatela i człowieka prywatnego. Rozdźwięk pozostał i rzutował na sposób doświadczania i przeżywania własnego istnienia”. Janion, Żmigrodzka, op. cit., s. 102, 103.

${ }^{55}$ Przybylski, op. cit., s. 121.

${ }^{56}$ Jak pisał Andrzej Walicki, powstanie to „uwidoczniło tragiczną przepaść między demokratycznym ruchem niepodległościowym a świadomością większości chłopstwa, dla którego słowo «Polska» kojarzyło się z niczym nieograniczonym uciskiem szlacheckim”. A. Walicki, Uniwersalizm i narodowość w polskiej myśli filozoficznej i koncepcjach mesjanistycznych epoki Romantyzmu (po roku 1831), [w:] Uniwersalizm i swoistość kultury polskiej, red. J. Kłoczowski, Lublin 1990, s. 55. E. Morawska, Wielka Emigracja o problemie swoistości kultury polskiej, [w:] ibid., s. 62.

${ }^{57}$ Ibidem. 
Chopin żył na styku tych środowisk, pomiędzy Polakami i Francuzami, pomiędzy kręgami arystokratycznymi a środowiskiem postępowych artystów-rewolucjonistów. Choć jako artysta był niewątpliwie nowatorem, może nawet „rewolucjonistą", to na francuskie salony wprowadzali go polscy arystokraci. Utrzymywał bliskie stosunki ze stronnictwem Hotel Lambert, na którego czele stał książę Adam Czartoryski. Członkiem tego stronnictwa był także Wojciech Grzymała, jeden z jego najbliższych przyjaciół i powierników. Stąd właśnie, już na początku filmu, przy śniadaniu, pojawia się polsko-francuskie nieporozumienie w ocenie wydarzeń w Galicji w roku 1846. Sand chciała widzieć w nich zaczyn europejskiej rewolucji, Polacy dostrzegli jedynie bezsensowną rzeź, naruszającą w dodatku tradycyjne hierarchie społeczne.

Żuławski, portretując w filmie polskich przyjaciół Chopina - Grzymałę, Czosnowską oraz służącego Jana - pokazał ich niedopasowanie do francuskich realiów i chaos, w jakim żyli. Jan naśladuje arystokratyczne maniery Chopina, Czosnowska to egzaltowana kokietka a Grzymała - rubaszny sybaryta. Żywiołowością temperamentów, polską wylewnością, próbują zagłuszyć rzeczywiste problemy. Żuławski pokazał ich naiwność; ale nie są to portrety jednostronne. Są to bowiem ludzie w gruncie rzeczy samotni i zagubieni. Mimo swej śmieszności posiadają także świadomość sytuacji, w jakiej się znaleźli, i pomimo że jest ona zabarwiona szlacheckim konserwatyzmem, nie jest to świadomość pozbawiona racji w stosunku do utopijnych poglądów ich francuskiej gospodyni.

W jednym z wywiadów Żuławski określił te poglądy i postawę Sand mianem „kawiorowej lewicowości”58, bowiem „Ta rewolucjonistka, paląca cygara, emancypantka, uwielbiana na całym świecie jako jakiś geniusz zupełny wolności ducha, ona swoim życiem pokazuje, że można być totalnie wolną, swobodną kobietą. Owszem, kiedy jest się bogatą" ${ }^{59}$ - tłumaczył reżyser.

Trzeba przyznać, że jest w tej krytyce słuszność. Potwierdza ją ocena rewolucji francuskiej roku 1848. Była to rewolucja robiona przez intelektualistów, którą cechował swoisty „werbalizm i irrealizm” będący wyrazem literackiej „deformacji profesjonalnej” ${ }^{60}$ oraz teatralizacji życia prywatnego i społecznego. „Uczestnicząca w rewolucji burżuazja zawodów literackich i wolnych podlegała jej z ogromną łatwością, nie zdając sobie oczywiście sprawy z ograniczenia własnej kondycji” ${ }^{61}$ - oceniała Maria Janion. Tak, czy inaczej: „werbalizm utopistów i idealistów, mielący frazesy i posługujący się wzniosłą symboliką postępowo-

${ }^{58}$ Żuławski. Przewodnik..., s. 389.

${ }^{59}$ Ibidem.

${ }^{60}$ M. Janion, Romantyczny teatr rewolucji, [w:] eadem, Czas formy otwartej, Warszawa 1984, s. 149 .

${ }^{61}$ Ibid., s. 150. 
-republikańską, utożsamiano chętnie z romantyzmem, bo w istocie i z niego się również oni wywodzili ${ }^{62}$ ".

W filmie Żuławskiego życie teatralizuje się na taką właśnie, romantyczną modłę. Tragedia zamienia się w farsę, melodramat w teatrzyk kukiełkowy. Efekt ten nasila się zwłaszcza w scenie wspólnej kolacji. Świetną partię rozgrywa wtedy Roman Wilhelmi (ostatnia jego rola filmowa) w roli Grzymały, który znakomicie odtworzył typ emigracyjnego Sarmaty - grubiańskiego i czułego zarazem. Grzymała przyznaje się do własnego bankructwa, zatajonego przed Chopinem romansu z panią Sand, a także - co gorsze - do konspiracyjnej zdrady, jakiej dopuścił się jeszcze przed wyjazdem z kraju ${ }^{63}$.

Faktycznie, rozpad związku Chopina i Sand zbiegł się z niepowodzeniami i bankructwem Grzymały jako przedsiębiorcy. Odtąd czekał go szary los emigranta, a „przyjaźń dochowana Chopinowi sprawiła, że po zerwaniu stosunków powieściopisarki z muzykiem Nohant stało się mu niedostępne, chociaż Grzymała utrzymywał nadal znajomość z George Sand ${ }^{64}$ ".

Ale los Chopina, mimo wszystkich podobieństw i uciążliwości, różnił się od życia reszty emigracji. Chopin był genialnym artystą, uwielbianym przez Francuzów, choć zazwyczaj stroniącym od zgiełku sławy. Był emigrantem z wyboru:

„Nie był właściwie emigrantem, ale podjąwszy decyzję pozostania na obczyźnie związała się łatwo z emigracyjną resztą, tym bardziej, że znalazł tam wielu dawnych znajomych i przyjaciół. Nie angażując się w rozgrywki polityczne najbliższy był kręgom Czartoryskich i Platerów" ${ }^{95}$.

${ }^{62}$ Ibidem.

${ }^{63} \mathrm{~W}$ swojej kreacji aktorskiej Wilhelmi oddał charakter oraz paradoksalność losów tej postaci. Prawdziwy Grzymała był w młodości adiutantem Księcia Poniatowskiego, po roku 1812 trzy lata przebywał w rosyjskiej niewoli, służył potem w administracji Królestwa Polskiego, a następnie wciągnął się w konspirację. Po wybuchu powstania listopadowego, w 1831 roku wyjechał do Paryża z misją pozyskania pożyczki dla powstańców. Odtąd znalazł poparcie w rodzinie Czartoryskich. Negocjował nawet zakup siedziby Hotelu Lambert dla stronnictwa Księcia Adama. Stał się bywalcem salonów francuskich, gdzie poznał m.in. Sand, Liszta i innych. Chopina znał jeszcze z Warszawy, a w Paryżu stał się dla niego ,powiernikiem i doradcą we wszystkich sprawach”. Znany był ze swej wesołości oraz słabości do kobiet. Jak pisze Zygmunt Markiewicz, „był on zapewne jednym z licznych kochanków George Sand, która przekazała go potomności pod postacią Salvatora w powieści Lukrecja Floriani. Zob. Z. Markiewicz, Przyjaciel Chopina (Wojciech Grzymała), [w:] eadem, Polsko-francuskie zwiazki literackie, Warszawa 1986, s. 314, 326 oraz Zamoyski, op. cit., s. 100.

${ }^{64}$ Markiewicz, op. cit., s. 323.

${ }^{65}$ Czartkowski, Jeżewska, op. cit., s. 199-200. Słowa te uzupełnić można charakterystyką Adama Zamoyskiego: „Chopin nie był tak oddany polskiej sprawie, jak by sobie życzyli liczni jego rodacy. Większość z nich była odcięta nie tylko od kraju, lecz również od swej pozycji społecznej 
Dbałość o szczegóły życia oraz muzyczny geniusz pozwoliły mu stworzyć taki wizerunek własnej osoby, który szybko otworzył przed nim bramy kariery artystycznej i publicznego powodzenia ${ }^{66}$. Chopin zrealizował tym samym bardzo francuski sen o społecznym wywyższeniu artysty ${ }^{67}$. Pomimo to krąg najbliższych ludzi był jednak wąski. „Sfera kontaktów egzystencjalnych zamykała się w kręgu przyjaciół polskich" ${ }^{68}$, znanych jeszcze z kraju, takich jak Jan Matuszyński, Julian Fontana, czy właśnie Grzymała. Z czasem dołączyła do nich nieliczna grupa artystów, pośród których szczególnie istotną rolę odgrywał Eugeniusz Delacroix.

W filmie Żuławskiego to właśnie Delacroix, obok Grzymały, jest człowiekiem najbliższym Chopinowi. W rozmowie prowadzonej pod malowniczym drzewem obok domu w Nohant obaj ironizują na temat powodzenia swojej sztuki na paryskich salonach. Żartobliwie określają siebie mianem snobów. Obaj zdają sobie jednak sprawę z rangi własnej sztuki. O podziwie Delacroix dla Chopina jako człowieka i artysty świadczy projekt plafonu do Pałacu Luksemburskiego, na którym kompozytor przedstawiony został jako Dante przekraczający Styks. Szkic do tego obrazu widzimy w filmie w rękach malarza, który pokazuje go Chopinowi.

Gest uczyniony w filmie przez Delacroix wskazuje już nie na sferę prozaicznych stosunków międzyludzkich, lecz na coś, co dla obu tych artystów stanowiło właściwą treść życia - ideał sztuki.

Życie Chopina związane było nie tylko z koniecznością wykreowania siebie jako artysty w oczach innych i nie tylko z bolączkami emigracji, lecz przede wszystkim z czymś, co Stanisław Brzozowski określił w Legendzie Młodej Polski jako romantyczne „przezwyciężanie rzeczywistości”' ${ }^{9}$. Wiązało się ono $\mathrm{z}$ wyjściem poza niemoc emigracyjnego wygnania za sprawą aktu woli oraz wiary w wartość pracy i siłę sztuki. To właśnie - obok realnych problemów - pokazał w swoim filmie Żuławski.

\footnotetext{
i źródeł utrzymania. Nadawało to ich patriotyzmowi nieco histeryczny charakter i popychało wielu spośród nich - zwłaszcza intelektualistów - w kierunku takiego, czy innego mistycyzmu (...) Jednakże jego patriotyzmu nie można kwestionować: hojnie wspierał wszystkie polskie instytucje charytatywne i zawsze angażował się w akcje służące sprawie narodowej (...) Jego patriotyzm i tęsknota za ojczyzną miały charakter metafizyczny. Nadal stanowiły główną inspirację większości jego utworów muzycznych, ale nie przekładały się na aktywność polityczną". Zamoyski, op. cit., s. $137-138$.

${ }^{66}$ Przybylski, op. cit., s. 93.

${ }^{67}$ Ibid., s. 112.

${ }^{68}$ M. Tomaszewski, Chopin. Człowiek, dzieło, rezonans, Kraków 2010, s. 15.

${ }^{69}$ S. Brzozowski, Legenda Młodej Polski. Studya o strukturze duszy kulturalnej, Kraków Wrocław 1983, s. 211.
} 
Trzeba przyznać, że reżyser unaocznił to w sposób tyleż efektowny, co oryginalny. Film mieni się gęstością znaczeń i zmiennością nastrojów. Filmowa opowieść i jej inscenizacja, tworzona jak gdyby w sposób rozkołysany, piętrzy się i urywa. Jest gwałtowna i zmienna niczym Chopinowskie tempo rubato, przypominające płomień rozedrgany na wietrze. Sceneria filmu przekonująco odtwarza klimat prawdziwego Nohant. Są tu rozległe plenery kręcone w pełnym słońcu i ciemne wnętrza domu, barwą i wystrojem sugerujące zamknięcie bohaterów w pułapce własnych przeżyć i obsesji. Obrazy filmu stworzone są w intensywnej tonacji kolorystycznej. Dominują kontrasty barwne i światłocieniowe. Kojarzą się one nie tylko z francuskim malarstwem pejzażowym i rodzajowym, lecz przede wszystkim z twórczością Delacroix.

Dynamikę inscenizacji współtworzy nieustanny ruch kamery, często podążającej za aktorami w sposób kolisty. Ekspresję obrazu wzmacnia oczywiście gra aktorska; jak zawsze w filmach Andrzeja Żuławskiego jest ona gwałtowna, w maksymalnym stopniu wykorzystująca cielesny gest; ten sposób gry aktorskiej, rozpostarty pomiędzy gwałtownym uniesieniem a uspokojeniem, wzmacnia zmienny rytm i tempo całego filmu.

Całość dopełnia oczywiście muzyka Chopina. Słychać ją w filmie niemal bez przerwy. Filmowy Chopin - Janusz Olejniczak grał ją podczas planu zdjęciowego na oryginalnym fortepianie marki Pleyel. Żuławski wykorzystał, w dłuższych lub krótszych fragmentach, kilkadziesiąt kompozycji. Są tu preludia ${ }^{70}$ otwierające film oraz nokturny zamykające jego akcję nocną porą ${ }^{71}$. Są fragmenty ballad, które wzmacniają balladowy charakter filmu i towarzyszą ważnym scenom ${ }^{72} . \mathrm{Za}$ dwa leitmotywy, sugerujące starcie śmierci i życia, uznać można Marsz Żałobny, czyli fragment Sonaty B-moll op. 35, odgrywany przez bohatera we fragmentach kilkakrotnie, oraz Barkarolę Fis-dur op. 60, jako muzyczną ewokację liryzmu i miłosnego uniesienia. Innymi słowy, muzyka Fryderyka Chopina w filmie Andrzeja Żuławskiego staje się uobecnieniem twórczego żywiołu i prawdziwym spełnieniem romantycznego ideału sztuki.

\section{SUMMARY}

The article discusses Andrzej Żuławski's film La Note Bleue [The Blue Note](1990). The author compares the events presented in the film with their factual, historical background. The history of the romance of Frederic Chopin and George Sands and the context

\footnotetext{
${ }^{70}$ Film otwiera, wraz z napisami czołowymi, Preludium $\mathrm{nr} 4$ E-moll op. 28.

${ }^{71}$ Nokturn C-moll op. 48 oraz czołówka końcowa: Nokturn E-moll nr 1 op. 72.

${ }^{72} \mathrm{Na}$ przykład Ballada nr 3 As-dur op. 47, w scenie ważnej rozmowy Chopina z Delacroix.
} 
of life of Polish composer in exile in France in the late 1840s form the main level of Żuławski's work. The existential experience of the main character bears the hallmarks of the "malady of the age", characteristic of Romanticism i.e. the state of alienation resulting from historical experiences, disappearance of religious feelings, and the feeling of volatility and instability of the world. For French Romantics from George Sand's circle the ideas of utopian socialism formed the antidote for "the malady of the age"; whereas Chopin looked for it in the ideal of musical art. Żuławski, comparing these two, historically known attitudes - Polish and French - created the work which refers to the Romantic conceptions of art that are close to those of Eugene Delacroix - in painting, and Chopin - in music. 